\title{
Simultaneous As(III) and Cd removal from copper smelting wastewater using granular $\mathrm{TiO}_{2}$ columns
}

\author{
Li Yan ${ }^{a}$, Yuying Huang ${ }^{b}$, Jinli Cui ${ }^{a}$, Chuanyong Jing ${ }^{a, *}$ \\ a State Key Laboratory of Environmental Chemistry and Ecotoxicology, Research Center for Eco-Environmental \\ Sciences, Chinese Academy of Sciences, Beijing 100085, PR China \\ b Shanghai Synchrotron Radiation Facility, Shanghai Institute of Applied Physics, Chinese Academy of Sciences, \\ Shanghai 201214, PR China
}

\section{A R T I C L E I N F O}

\section{Article history:}

Received 7 July 2014

Received in revised form

17 September 2014

Accepted 13 October 2014

Available online 29 October 2014

\section{Keywords:}

Metallurgical wastewater

Granular $\mathrm{TiO}_{2}$

Fixed-bed columns

Adsorbent regeneration

On-line treatment process

\begin{abstract}
A B S T R A C T
Remediation of metallurgical industry wastewater has presented a great environmental challenge for decades. In this study, a complete remediation technology was proposed for simultaneous As(III) and Cd adsorptive removal, adsorbent regeneration, and recovery of As and Cd. Using three granular $\mathrm{TiO}_{2}$ columns in series, As(III) and Cd in the raw water at $2590 \pm 295$ and $12 \pm 2 \mathrm{mg} / \mathrm{L}$, respectively, could be reduced to $0.16 \pm 0.11$ and $0.0133 \pm 0.0134 \mathrm{mg} / \mathrm{L}$, well below the wastewater discharge limit. Spent $\mathrm{TiO}_{2}$ media could be regenerated using $\mathrm{H}_{2} \mathrm{SO}_{4}$ and $\mathrm{NaOH}$, and the regenerated adsorbent could be re-used for at least 10 treatment cycles and 770 bed volumes with no decrease in its adsorption capacity. Remediation of $1 \mathrm{~L}$ wastewater generated $0.89-1.5 \mathrm{~g}$ solid residue which could be used as an intermediate for the As and Cd chemical refinement. The waste solution can be further treated after mixing with raw water to adjust the raw $\mathrm{pH}$ from 1.4 to 7 . This adsorption, regeneration, and reuse process provides an innovative technology for metallurgical industry wastewater remediation that is promising for practical application.
\end{abstract}

(c) 2014 Elsevier Ltd. All rights reserved.

\section{Introduction}

Mining and smelting are major industrial processes that are associated with multiple toxic metal contaminants (Bian et al., 2012). In these industrial wastewaters, coexistence of As(III) and $\mathrm{Cd}$ is a great public concern because of their carcinogenicity (Barrett, 2012; Lubin et al., 2008). Thus, developing effective and robust wastewater treatment technology for simultaneous As(III) and Cd removal has motivated extensive research (Allende et al., 2012; Deschamps et al., 2005; Dey et al., 2009; Jiang et al., 2014; Johnson and Hallberg, 2005).

Many efforts have been made to solve this problem over past decades, with the result that neutralization-precipitation has been adopted as a commonly used method for removal of heavy metals, including $\mathrm{As}(\mathrm{III})$ and $\mathrm{Cd}$, from mining and smelting wastewaters (Dong et al., 2011; McDonald et al., 2006; Wang et al., 2003). For example, an approach using iron precipitation and high density sludge (HDS) recycling has become a benchmark procedure in acid mine drainage treatment (Dey et al., 2009). This HDS process requires increasing the $\mathrm{pH}$ with hydrated lime and subsequently adding iron salts to form precipitates with As. However, HDS generates large volumes of sludge with low chemical stability (Dey et al., 2009; McDonald et al., 2006), which may release As under the attack of carbon dioxide (Nishimura and Robins, 1998; Pantuzzo and Ciminelli, 2010).

\footnotetext{
* Corresponding author. Tel./fax: +86106284 9523.

E-mail address: cyjing@rcees.ac.cn (C. Jing). 
Recent studies have employed various adsorbents to remove As from wastewater (Adra et al., 2013; Dou et al., 2013; Luo et al., 2010; Mohan and Pittman Jr, 2007; Mueller et al., 2010), and the results indicate that $\mathrm{TiO}_{2}$ is a promising material for As removal due to its high adsorption affinity and chemical stability (Guan et al., 2012). Our previous study demonstrated that regenerable and reusable nanocrystalline $\mathrm{TiO}_{2}$ can remediate acidic metallurgical wastewater with As(III) concentrations at the g/L levels (Luo et al., 2010). However, the use of nanocrystalline $\mathrm{TiO}_{2}$ requires laborious solid/ liquid separation in the treatment chain, and the possible leakage of As-adsorbed nano $\mathrm{TiO}_{2}$ presents an environmental risk if not safely disposed of (Luo et al., 2013). To prevent the potential loss of nanomaterials, granular adsorbents based such as iron dust, bone char, and micrite have been evaluated for the treatment of synthetic acid mine drainage with $5 \mathrm{mg} / \mathrm{L}$ As(V) (Liu et al., 2013). However, these granular media have low As adsorption capacity $(2.7-6.6 \mathrm{mg} / \mathrm{g}$ ) and are unsuitable for remediation of industrial wastewaters with As concentrations at the $\mathrm{g} / \mathrm{L}$ levels. In addition, these granular media are generally designed for one time use only, and the disposal of spent media involves additional economic and environmental concerns. Our approach to solve this problem is to use regenerable granular $\mathrm{TiO}_{2}$ in a fixed-bed column. Granular $\mathrm{TiO}_{2}$ based As removal from groundwater has been investigated in previous study (Bang et al., 2005). However, no attempt to use granular $\mathrm{TiO}_{2}$ in the remediation of metallurgical wastewater has been reported. As a proof-of-concept study herein, we implemented a granular $\mathrm{TiO}_{2}$ based complete treatment chain to remediate copper smelting wastewater with $2590 \mathrm{mg} / \mathrm{L} \mathrm{As(III)}$ and $12 \mathrm{mg} / \mathrm{L} \mathrm{Cd}$.

The objective of this study was to establish an innovative metallurgical wastewater treatment process using granular $\mathrm{TiO}_{2}$. This process integrates the simultaneous removal of As(III) and Cd from wastewater, regeneration of adsorbent, and recovery of As and Cd. This adsorption-regenerationreuse treatment process results in successful remediation and "zero" residue, and can avoid the possibility of secondary pollution and reduce the post-treatment cost.

\section{Materials and methods}

\subsection{Materials}

The raw water was obtained from a copper smelting company in China (Luo et al., 2010). The stock solutions of As(III) and Cd were prepared by dissolving $\mathrm{NaAsO}_{2}$ and $\mathrm{Cd}\left(\mathrm{NO}_{3}\right)_{2}$ in deionized (DI) water solution. The $\mathrm{TiO}_{2}$ used in this study was prepared by hydrolysis of titanyl sulfate as detailed in the supplementary materials (SM) (Jing and Cui, 2011). Granular $\mathrm{TiO}_{2}$ of $40-60$ mesh $(250-380 \mu \mathrm{m})$ with BET of $196 \mathrm{~m}^{2} / \mathrm{g}$ was used in this study.

\subsection{Adsorption isotherm}

Adsorption isotherm experiments were performed to determine the As(III) and Cd adsorption capacity on granular $\mathrm{TiO}_{2}$ in $0.04 \mathrm{M} \mathrm{NaClO}_{4}$ solution. Suspension samples containing 0.39-2460 mg/L As(III) or 0.05-1470 mg/L Cd and $2.5 \mathrm{~g} / \mathrm{L} \mathrm{TiO}_{2}$ were adjusted to $\mathrm{pH} 5$ and 7 with $\mathrm{NaOH}$ and $\mathrm{HClO}_{4}$. The solutions were purged with nitrogen for an hour to remove $\mathrm{O}_{2}$ and $\mathrm{CO}_{2}$. After the samples were mixed on a rotator for $72 \mathrm{~h}$ in the dark, the final $\mathrm{pH}$ was measured and the suspensions were filtered through a $0.45-\mu \mathrm{m}$ membrane filter for soluble arsenic and cadmium measurements.

\subsection{As(III) and Cd removal using granular $\mathrm{TiO}_{2}$ columns}

The flowchart of the wastewater treatment is shown in Fig. 1. The $\mathrm{pH}$ of the raw water was adjusted from 1.4 to 4 using $10 \mathrm{wt}$ $\%$ lime, and then to $\mathrm{pH} 7$ using industrial grade $\mathrm{NaOH}$. The water contained an average concentration of $2590 \pm 295 \mathrm{mg} / \mathrm{L}$ $\mathrm{As}(\mathrm{III})$ and $12 \pm 2 \mathrm{mg} / \mathrm{L} \mathrm{Cd}$, which was treated using three $\mathrm{TiO}_{2}$ columns in series. When granular $\mathrm{TiO}_{2}$ in the first column was saturated, the spent media in this column was transferred into a $100 \mathrm{~mL}$ Teflon container for regeneration. The regenerated granular $\mathrm{TiO}_{2}$ was reused as the last column in the next cycle, and the other two columns were shifted forward in sequence. In this way, the first column always has the highest adsorption loading and the last column has the highest available adsorption capacity, to safeguard the effluent quality.

The column parameters are summarized in Table 1. In a typical setting, granular $\mathrm{TiO}_{2}(20 \mathrm{~g})$ was packed in a $1.2 \mathrm{~cm}$ inner diameter glass column, resulting in $16 \mathrm{~cm}$ height and $18 \mathrm{~mL}$ volume. The columns were covered with aluminum foil to prevent light exposure. The upflow rate was designed at $0.6 \mathrm{~mL} / \mathrm{min}$ with an empty bed contact time (EBCT) of $30 \mathrm{~min}$ for each column.

\subsection{Granular $\mathrm{TiO}_{2}$ regeneration}

The spent granular $\mathrm{TiO}_{2}(20 \mathrm{~g})$ was regenerated in the following procedure. First, acid regeneration was employed to

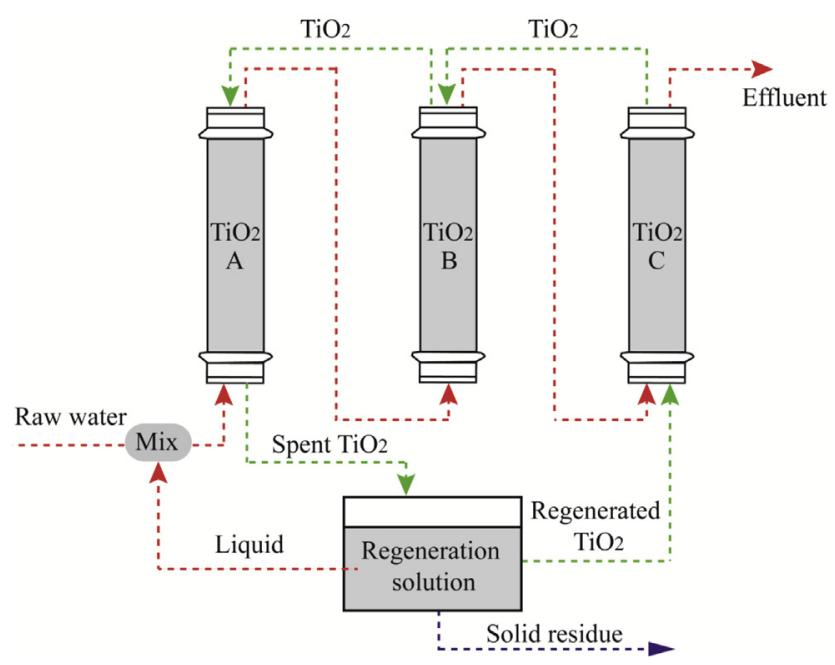

Fig. 1 - Schematic flowchart for the proposed industrial wastewater treatment process. The red and green dotted lines represent the flow of liquid and $\mathrm{TiO}_{2}$ solid, respectively. (For interpretation of the references to colour in this figure legend, the reader is referred to the web version of this article.). 
Table 1 - Column parameters.

\begin{tabular}{ll} 
Parameter & \multicolumn{1}{c}{ Column } \\
\hline Mass of granular $\mathrm{TiO}_{2}(\mathrm{~g})$ & 20 \\
$\mathrm{TiO}_{2}$ particle size & $40-60$ mesh $(250-380 \mu \mathrm{m})$ \\
Column diameter $(\mathrm{cm})$ & 1.2 \\
Bed depth $(\mathrm{cm})$ & 16 \\
EBCT $(\mathrm{min})$ & 30 \\
Flow rate $(\mathrm{mL} / \mathrm{min})$ & 0.6 \\
Hydraulic loading rate $(\mathrm{cm} / \mathrm{min})$ & 0.53 \\
Initial As(III) concentration $(\mathrm{mg} / \mathrm{L})$ & $2590 \pm 295$ \\
Initial Cd concentration $(\mathrm{mg} / \mathrm{L})$ & $12 \pm 2$
\end{tabular}

extract cations by reacting with $70 \mathrm{~mL} 0.5 \mathrm{M} \mathrm{H}_{2} \mathrm{SO}_{4}$ on a rotator for $2 \mathrm{~h}$. Then, the media was rinsed with $70 \mathrm{~mL}$ tap water. The media was then mixed with $70 \mathrm{~mL} 5 \mathrm{M} \mathrm{NaOH}$ solution for $2 \mathrm{~h}$, and rinsed with $70 \mathrm{~mL}$ tap water. This alkali wash was repeated three times to maximize the desorption of As(III) from $\mathrm{TiO}_{2}$. Finally, $70 \mathrm{~mL} 0.5 \mathrm{M} \mathrm{H}_{2} \mathrm{SO}_{4}$ solution was applied to adjust $\mathrm{pH}$ to neutral.

\subsection{Recovery of As and Cd from regeneration solution}

The above acid and alkali regeneration solutions were mixed and precipitates were formed. After solid/liquid separation by centrifugation at $8000 \mathrm{rpm}$ for $15 \mathrm{~min}$, the solids were freeze-dried before characterization using X-ray absorption near edge structure (XANES), X-ray diffraction (XRD), scanning electron microscopy and energy dispersive X-ray (SEM-EDX). The residue liquid after recovery was recycled and mixed with raw wastewater as influent in the next adsorptionregeneration-reuse cycle.

\subsection{Characterization}

$\mathrm{X}$-ray powder diffraction (XRD) data were recorded on a Rigaku D/Max-2500 diffractometer at $40 \mathrm{kV}, 100 \mathrm{~mA}$ using a $\mathrm{Cu}$-target tube and a graphite monochromator. Scans were performed in the $2 \theta$ range of $5^{\circ}-90^{\circ}$ with a step size of $0.01^{\circ}$ and a count time of $2 \mathrm{~s}$ per step. The PDF-2 reference database from the international center for diffraction database was used to analyze the XRD patterns. A Hitachi S-3000N scanning electron microscope (SEM) with an Oxford energy dispersive $\mathrm{X}$-ray (EDX) analyzer was used for qualitative analysis of the solid residue from adsorbent regeneration. EDX mapping was used to examine the dominant elements in the solid residue. The solid residue was analyzed using XANES on beamline BL14W1 at the Shanghai Synchrotron Radiation Facility (SSRF), China. XANES spectra were acquired from -150 to $300 \mathrm{eV}$ relative to the As K-edge of 11,867 eV. Elemental arsenic $\left(\mathrm{As}^{0}\right)$ was used to calibrate the energy at 11,867 eV. The spectra were collected in fluorescence mode. $\mathrm{Na}_{2} \mathrm{HAsO}_{4} \cdot 7 \mathrm{H}_{2} \mathrm{O}$ and $\mathrm{NaAsO}_{2}$ spectra were also collected and analyzed as standard references. The XANES spectra were analyzed using a linear combination fit in the Athena program in the IFEFFIT package (Ravel and Newville, 2005).

\subsection{Sample analysis}

A furnace atomic absorption spectrometer (FAAS, Perkin-Elmer AAS-800) was used to measure the total concentration of As and Cd. The As speciation was determined by a high performance liquid chromatography atomic fluorescence spectrometer (HPLC-AFS, Jitian, China). Separation of As compounds was carried out in a Hamilton PRP-X100 anion exchange column, using $10 \mathrm{mM}$ phosphate buffer at $\mathrm{pH} 5.8$ as mobile phase at $1.0 \mathrm{~mL} / \mathrm{min}$ flow rate. The quality assurance/ quality control procedure followed that of our previous studies (Cui et al., 2013; Luo et al., 2010). Extended X-ray absorption fine structure (EXAFS) spectroscopy was used to explore the adsorption mechanism of wastewater $\mathrm{As}$ (III) on granular $\mathrm{TiO}_{2}$, and the information is detailed in the SM.

\section{Results and discussion}

\subsection{Granular $\mathrm{TiO}_{2}$ adsorption capacities for $\mathrm{As}$ (III) and} Cd

The adsorption isotherms of $\mathrm{As}(\mathrm{III})$ and Cd conformed to Langmuir model (Fig. 2), and the fitting parameters were presented in Table S1. Neutrally charged As(III) and cationic Cd exhibited different adsorption behaviors on granular $\mathrm{TiO}_{2}$. Specifically, the adsorption capacity for As(III) ranged from 145 to $160 \mathrm{mg} / \mathrm{g}$ when $\mathrm{pH}$ increased from 5 to 7 (Fig. 2-I). On the other hand, the $\mathrm{Cd}$ adsorption capacity substantially increased from $57 \mathrm{mg} / \mathrm{g}$ at pH 5 to $380 \mathrm{mg} / \mathrm{g}$ at pH 7 (Fig. 2-II). Compared with As(III) adsorption capacity of $2.2-102.3 \mathrm{mg} / \mathrm{g}$ on powder (hydrous) or granular $\mathrm{TiO}_{2}$ found in previous
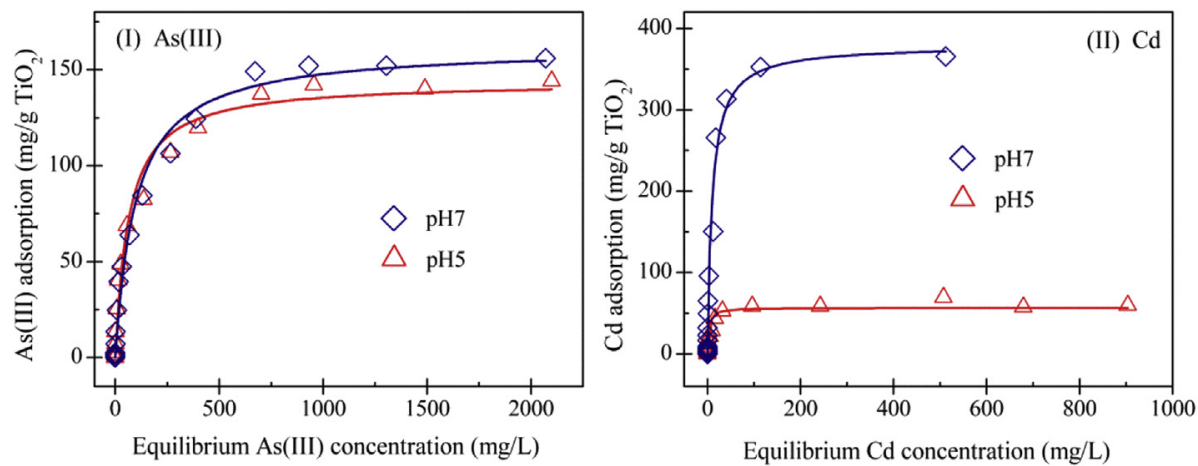

Fig. 2 - Adsorption of (I) As(III) and (II) Cd (point) on $\mathrm{TiO}_{2}$ and Langmuir modeling (line) at pH 5 and 7. 
studies at pH 4-9 (Bang et al., 2005; Guan et al., 2012; Xu et al., 2010), our granular $\mathrm{TiO}_{2}$ exhibited a higher value (145-160 mg/ g). Meanwhile, the $\mathrm{Cd}$ adsorption capacity has been reported to be in the range $3.9-56.0 \mathrm{mg} / \mathrm{g} \mathrm{TiO}_{2}$ with different particle size at pH 6.1 (Gao et al., 2004), an order of magnitude smaller than the present granular $\mathrm{TiO}_{2}$. The high adsorption capacity of granular $\mathrm{TiO}_{2}$ in this study may be attributed to the high As(III) and Cd initial concentrations, which ensures its utility to treat real industrial wastewaters.

\subsection{As(III) and $\mathrm{Cd}$ removal using granular $\mathrm{TiO}_{2}$ columns}

Simultaneous As(III) and Cd removal was achieved using three consecutive granular $\mathrm{TiO}_{2}$ columns, and the effluent concentrations were below the regulatory requirements (Figs. 3 and 4). For instance, the influent As(III) concentration at $2590 \pm 295 \mathrm{mg} / \mathrm{L}$ was decreased to $0.16 \pm 0.11 \mathrm{mg} / \mathrm{L}$, and Cd was reduced from $12 \pm 2 \mathrm{mg} / \mathrm{L}$ to $0.0133 \pm 0.0134 \mathrm{mg} / \mathrm{L}$. The effluent concentrations were well below the Chinese industrial wastewater discharge limit, $0.5 \mathrm{mg} / \mathrm{L}$ for As and $0.1 \mathrm{mg} / \mathrm{L}$ for $\mathrm{Cd}$. Although in some cycles, the effluent $\mathrm{Cd}$ concentration from the 3rd columns was higher than that in other two, the effluent $\mathrm{Cd}$ concentrations were all below the discharge limit of industrial wastewater in each treatment cycle (Fig. 4). Our results suggest that over $98 \% \mathrm{As}$ (III) and nearly $100 \% \mathrm{Cd}$ in wastewater can be removed in the treatment chain. The As speciation analysis indicated that no $\mathrm{As}(\mathrm{V})$ was detected in the treatment chain.

During the column experiments, the $\mathrm{pH}$ of the influent was decreased from 7.0 to $5.9 \pm 0.8$ in the effluent (Fig. S1), within the range for industrial wastewater discharge permits (6-9). This $\mathrm{pH}$ decrease can be attributed to surface complexation reactions of $\mathrm{As}$ (III) and $\mathrm{Cd}$ that resulted in the net release of one and two protons, respectively. The surface complexation reactions evidenced by EXAFS studies are descried as follows (Collins et al., 1999; Janusz and Matysek, 2006; Pena et al., 2006; Randall et al., 1999):

$\mathrm{H}_{3} \mathrm{AsO}_{3}+2(>\mathrm{TiOH})=(>\mathrm{TiO})_{2} \mathrm{AsO}^{-}+\mathrm{H}^{+}+2 \mathrm{H}_{2} \mathrm{O}$

$\mathrm{Cd}\left(\mathrm{H}_{2} \mathrm{O}\right)_{6}{ }^{2+}+2(>\mathrm{TiOH})=(>\mathrm{TiO})_{2} \mathrm{Cd}\left(\mathrm{H}_{2} \mathrm{O}\right)_{4}+2 \mathrm{H}^{+}+2 \mathrm{H}_{2} \mathrm{O}$

Our As K-edge EXAFS analysis for spent $\mathrm{TiO}_{2}$ (Fig. S2 and S3, Table S2) indicates that As(III) formed a bidentate binuclear inner-sphere complex on the $\mathrm{TiO}_{2}$ surface without Cd-As(III)$\mathrm{TiO}_{2}$ ternary surface complex or surface precipitate existed in this study.

\subsection{Granular $\mathrm{TiO}_{2}$ regeneration and reuse}

Extraction using $0.5 \mathrm{M} \mathrm{H}_{2} \mathrm{SO}_{4}$ followed by $5 \mathrm{M} \mathrm{NaOH}$ could release $97 \%$ of adsorbed As(III) and $66 \%$ of adsorbed Cd
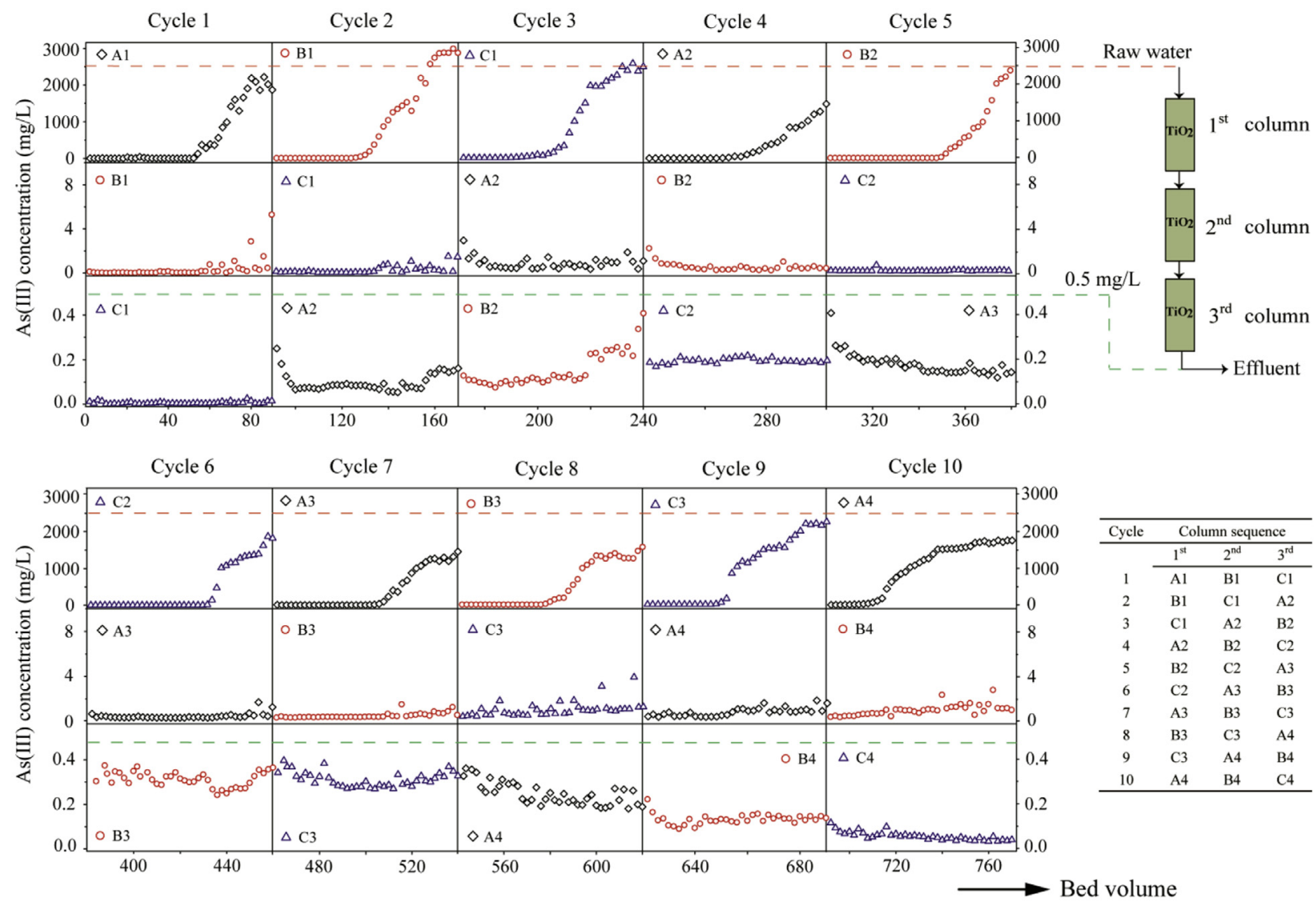

Fig. 3 - Effluent As(III) concentrations from three columns in series as a function of bed volume. Diamonds: column A, Circles: column B, Triangles: column $C$. The numbers after the $A, B$, and $C$ column represent the number of times that the column was regenerated and reused. 

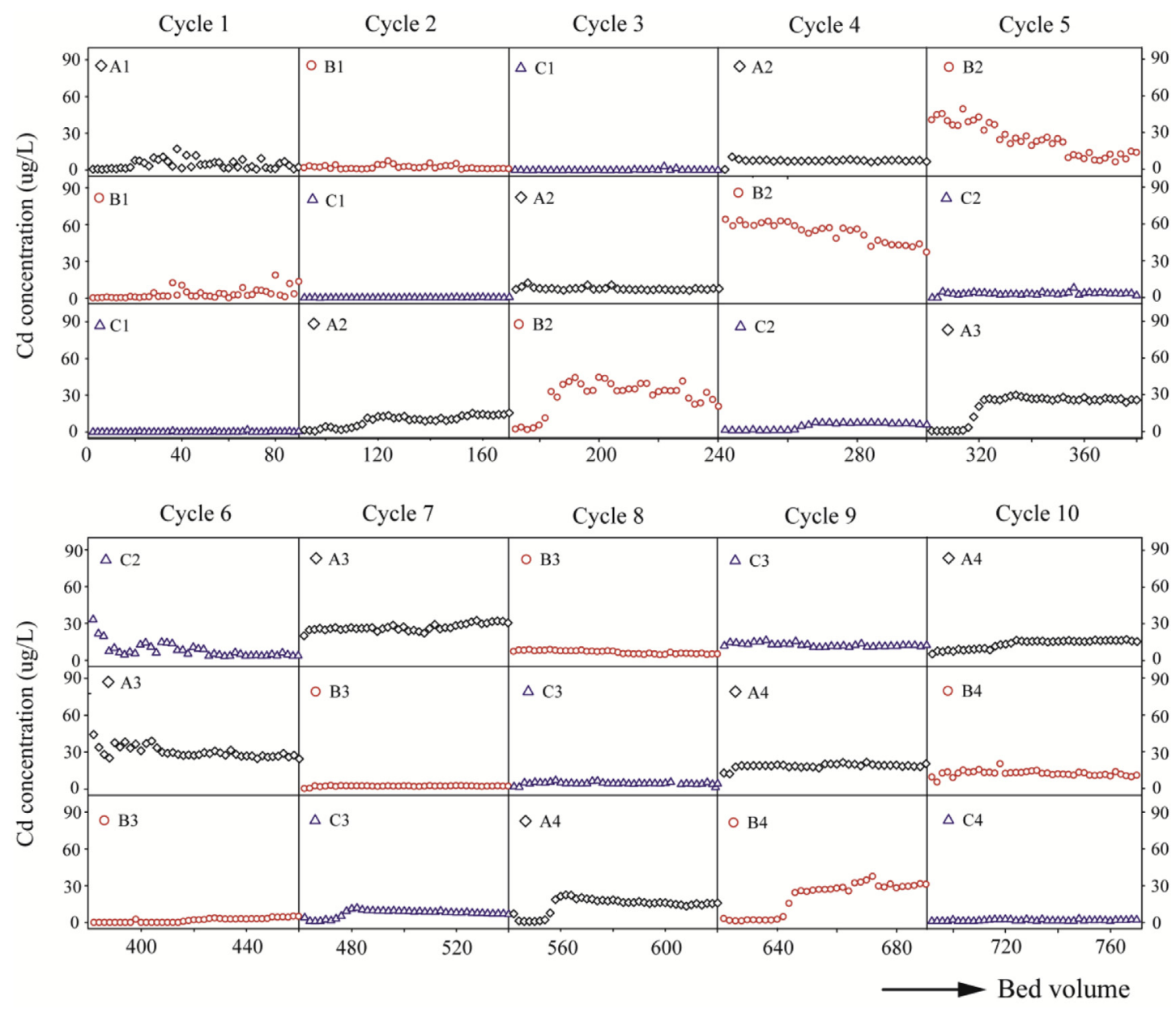

Fig. 4 - Effluent Cd concentrations from three columns in series as a function of bed volume. Diamonds: column A, Circles: column B, Triangles: column $C$. The numbers after the $A, B$, and $C$ column represent the number of times that the column was regenerated and reused.

(Fig. S4). The desorption kinetics indicated that the aqueous As concentration reached equilibrium after mixing with $\mathrm{H}_{2} \mathrm{SO}_{4}$ and $\mathrm{NaOH}$ for $2 \mathrm{~h}$ (Fig. S5). Therefore, the spent granular $\mathrm{TiO}_{2}$ was regenerated by mixing with $0.5 \mathrm{M} \mathrm{H}_{2} \mathrm{SO}_{4}$ and subsequently $5 \mathrm{M} \mathrm{NaOH}$ for $2 \mathrm{~h}$. Under this optimized condition, the total desorption ratio was in the range 76-93\% for As(III) in 10 treatment cycles, and $62-89 \%$ for Cd (Fig. S6 and S7). The regenerated granular $\mathrm{TiO}_{2}$ was then reused to treat the mixture of raw water and waste solution from $\mathrm{TiO}_{2}$ regeneration with average As and Cd concentrations of $2590 \pm 295$ and $12 \pm 2 \mathrm{mg} / \mathrm{L}$, respectively (Fig. 1).

The $60-\mathrm{g}$ granular $\mathrm{TiO}_{2}$ in three consecutive columns was effective in As(III) and Cd removal for more than 10 treatment cycles in 770 bed volumes (BVs) (Figs. 3 and 4). Here, it is noteworthy that considering the recycle of residual liquid (about $40 \%$ of the treated water), about 462 BVs ( $8316 \mathrm{~mL}$ raw water) were actually treated. The mass balance calculation indicates that the average concentration of $\mathrm{As}$ (III) and $\mathrm{Cd}$ loaded on the first $\mathrm{TiO}_{2}$ column in each treatment cycle was $162 \pm 20$ and $1.00 \pm 0.16 \mathrm{mg} / \mathrm{g}$, respectively (Fig. 5). This As(III) adsorption capacity was in line with the adsorption isotherm results $\left(145-160 \mathrm{mg} / \mathrm{g}\right.$, Fig. 2-I), indicating that the first $\mathrm{TiO}_{2}$ column reached its maximum As(III) adsorption capacity in each cycle. Compared with the adsorption capacity of reported granular adsorbents $(0.16-32.4 \mathrm{mg} / \mathrm{g}$ ) (Badruzzaman et al., 2004; Bang et al., 2005; Dou et al., 2013; Gibbons and Gagnon, 2010; Liu et al., 2013), the granular $\mathrm{TiO}_{2}$ in this study

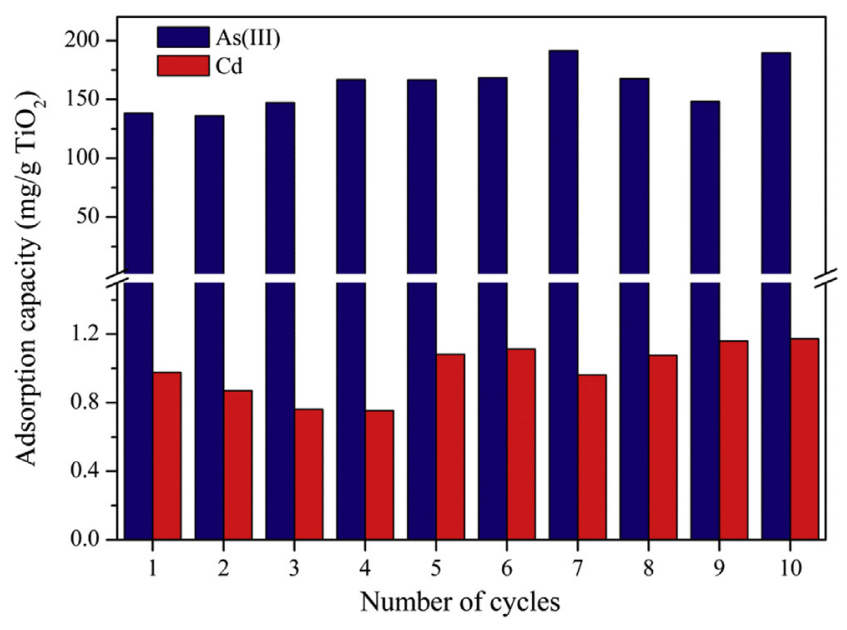

Fig. 5 - $\mathrm{TiO}_{2}$ adsorption capacity for $\mathrm{As}(\mathrm{III})$ and $\mathrm{Cd}$ in 10 treatment cycles. 
exhibited high As(III) adsorption capacity (145-160 mg/g). The reason may be ascribed to higher initial As(III) concentration (2590 $\mathrm{mg} / \mathrm{L}$ ) and longer EBCT (30 $\mathrm{min})$ than that in previous studies with As concentration in range $0.043-5 \mathrm{mg} / \mathrm{L}$ and EBCT of 2-15 min. Nevertheless, the Cd loading on the first $\mathrm{TiO}_{2}$ column $(1.00 \pm 0.16 \mathrm{mg} / \mathrm{g})$ was appreciably lower than its adsorption capacity $(57-380 \mathrm{mg} / \mathrm{g}$, Fig. 2-II). The significant difference can be attributed to the relatively low Cd concentration in the raw water $(12 \mathrm{mg} / \mathrm{L})$.

The XRD patterns of pristine and spent $\mathrm{TiO}_{2}$ shown in Fig. S8 exhibit no change in crystalline structure and $\mathrm{TiO}_{2}$ remained in the anatase form (PDF \#21-1272). The chemical stability of $\mathrm{TiO}_{2}$ ensures its high effectiveness after regeneration, which enables its reuse in the following cycle.

\subsection{Recovery of As and Cd from regeneration solution}

Precipitation occurred when the acid and alkali regeneration solutions were mixed (Fig. S9). Remediation of $1 \mathrm{~L}$ wastewater could produce $0.89-1.5 \mathrm{~g}$ solid residue (dry weight), and 35-46\% desorbed As(III) (553-897 mg) and >99.8\% desorbed Cd $(10.7 \pm 1.4 \mathrm{mg})$ were in the precipitate based on mass balance calculation. The SEM-EDX results show the dominant elements in solid residue were O (39.9\%), Na (27.3\%), As (11.1\%), and $\mathrm{Ca}(6.4 \%)$, with trace amounts of $\mathrm{S}(2.0 \%), \mathrm{Ti}(1.9 \%)$ and $\mathrm{Cd}$ (0.57\%) (Fig. S10). Furthermore, the As in the solid residue was composed of $25.2 \% \mathrm{As}(\mathrm{V})$ and $74.8 \% \mathrm{As}(\mathrm{III})$, as evidenced by our XANES analysis (Fig. S11). The existence of $\mathrm{As}(\mathrm{V})$ indicated that the strong alkali condition during the regeneration process may facilitate the oxidation of As(III). Our XRD analysis demonstrates the presence of $\mathrm{NaAsO}_{2}$ (PDF \#07-0009), $\mathrm{NaCaAsO}_{4}$ (PDF \#27-0664), and $\mathrm{Na}_{2} \mathrm{CdO}_{2}$ (PDF \#36-1199) (Fig. S12), which could be used as a raw material for the production of As and Cd chemicals.

The volume of residual liquid was about $40 \%$ of the treated water. The As concentration in the residue liquid was approximately $2500 \mathrm{mg} / \mathrm{L}$, which was comparable to that in the influent $(2590 \pm 295 \mathrm{mg} / \mathrm{L})$. The As speciation analysis showed that an average of $14.9 \%$ As was in the $\mathrm{As}(\mathrm{V})$ form. Conversely, only $\mu \mathrm{g} / \mathrm{L}$ level $\mathrm{Cd}$ was detected in the residue liquid. The residual liquid was then mixed with raw water at a volume ratio of 2:5 to adjust the influent $\mathrm{pH}$ to 7 , resulting in about $4.1 \% \mathrm{As}(\mathrm{V})$ in the influent. Thus, the residual liquid was recycled and its alkalinity was used to neutralize the acidity in the raw water.

\subsection{Evaluation of small column tests}

Accurate prediction of As(III) breakthrough curves from the fixed-bed system is important in facility design and operation. A close examination of the As(III) breakthrough profile in Fig. 6 shows its similarity in the three consecutive columns, with a substantial steep curve for the first column. The three small columns in series can be considered as three sections of one large column with sampling ports placed at the top (i.e., after $30 \mathrm{~min}$ EBCT), middle (i.e., after $60 \mathrm{~min}$ EBCT), and bottom (i.e., after 90 min EBCT) (Westerhoff et al., 2006). Incorporating sampling ports in one large column helps to understand the effect of EBCT. For example, the As(III) concentration from the top sampling port reached $0.5 \mathrm{mg} / \mathrm{L}$ at about 32 bed volumes,

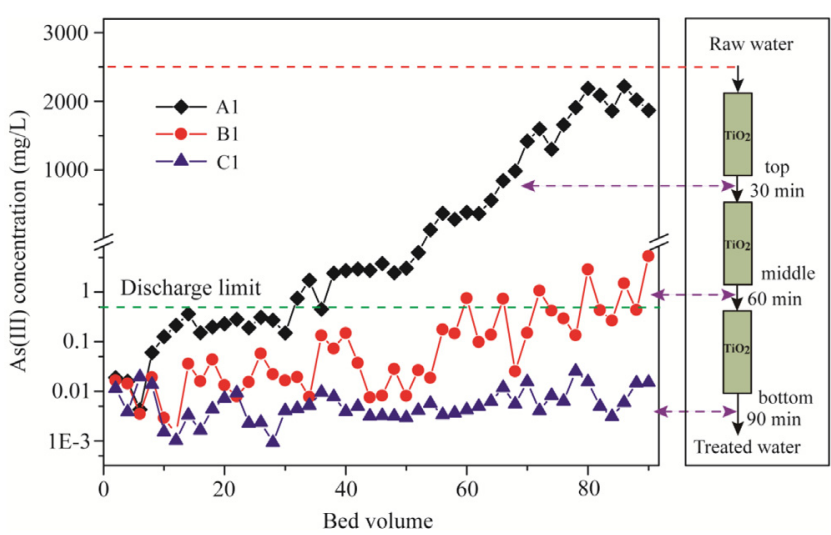

Fig. 6 - As(III) breakthrough curves of three columns in series in cycle 1.

whereas the effluent (i.e., the bottom sampling port) was below $0.03 \mathrm{mg} / \mathrm{L}$ up to 90 bed volumes (Fig. 6). The results clearly demonstrate that enhanced As(III) removal can be achieved with extended EBCT (Westerhoff et al., 2005; Zeng et al., 2008).

Individual column port data provide the opportunity to evaluate the efficiency of the treatment chain. The As(III) adsorption density ( $\left.q_{\text {column }}\right)$ in the first and second $\mathrm{TiO}_{2}$ column was 80.9 and $11.5 \mathrm{mg} / \mathrm{g}$, respectively, when their effluent As(III) concentration reached $0.5 \mathrm{mg} / \mathrm{L}$, whereas the effluent As(III) concentration from the third $\mathrm{TiO}_{2}$ column never reached $0.5 \mathrm{mg} / \mathrm{L}$, the discharge limit. At 90 bed volumes, the As(III) concentration from the first column port reached $2220 \mathrm{mg} / \mathrm{L}$ (i.e., $86 \%$ of raw water at $2590 \mathrm{mg} / \mathrm{L}$ ), and the second column port was only $5.3 \mathrm{mg} / \mathrm{L}$ (i.e., $0.2 \%$ of raw water at $2590 \mathrm{mg} / \mathrm{L}$ ) (Fig. 6). Based on the mass balance calculation, when $\mathrm{TiO}_{2}$ in the first column was saturated, $55-73 \%$ of $\mathrm{TiO}_{2}$ in the second column would be available for adsorption. Therefore, the column operation in a series configuration would be beneficial to take advantage of the $\mathrm{TiO}_{2}$ adsorption capacity in the second and third column after forwarding the columns in sequence in the next treatment cycle as shown in Fig. 1 (Kanematsu et al., 2012; Westerhoff et al., 2006).

As a proof-of-concept study herein, the results obtained with laboratory small columns packed with granular $\mathrm{TiO}_{2}$ can be used to simulate the performance of pilot or full-scale systems. The breakthrough curves of small and large columns are expected to be analogous because of the similarity in mass transfer and hydrodynamic characteristics (Crittenden and Weber, 1978a, b; Kanematsu et al., 2012). Thus, the proportional diffusion (PD) scaling approach could be used to design a full-scale column because of its successful performance predication of such systems (Kanematsu et al., 2012; Westerhoff et al., 2006, 2005). In the PD scaling approach, the relationships among empty bed contact time (EBCT), particle diameter $\left(d_{p}\right)$, operating duration $(t)$, hydraulic loading rate (V), Reynolds number (Re), Schmidt number (Sc) are related together according to the following equations:

$\frac{\mathrm{EBCT}_{\mathrm{SC}}}{\mathrm{EBCT}_{\mathrm{LC}}}=\left[\frac{\mathrm{d}_{p, \mathrm{SC}}}{\mathrm{d}_{p, \mathrm{LC}}}\right]=\frac{\mathrm{t}_{\mathrm{SC}}}{\mathrm{t}_{\mathrm{LC}}}$ 
$\frac{\mathrm{V}_{\mathrm{SC}}}{\mathrm{V}_{\mathrm{LC}}}=\left[\frac{\mathrm{d}_{p, \mathrm{LC}}}{\mathrm{d}_{p, \mathrm{SC}}}\right] \times \frac{\mathrm{Re}_{\mathrm{SC}} \times \mathrm{Sc}}{\mathrm{Re}_{\mathrm{LC}} \times \mathrm{SC}}$

The subscript LC and SC in the above equations indicated large-scale and small-scale column, respectively. The magnitude of $\operatorname{Re}_{\mathrm{LC}} \times \mathrm{Sc}$ was set to 2000 in this study to minimize axial dispersion, and this value is generally used to scale up granular iron oxide columns for As(V) removal (Kanematsu et al., 2012; Westerhoff et al., 2006, 2005). The detailed calculation and list of large column design parameters are presented in the SM.

According to the parameters of the full-scale column (Table S5), three columns of $2.6 \mathrm{~m}$ in diameter and $3.8 \mathrm{~m}$ in height with granular $\mathrm{TiO}_{2}$ (20-40 mesh) weighted 22,222 kg in each column should be implemented to remediate $500 \mathrm{~m}^{3}$ wastewater per day. The average solid waste in this proposed system is about $600 \mathrm{~kg}$, much less than the $70 \mathrm{t} / \mathrm{d}$ sludge from the traditional HDS process (Luo et al., 2010).

\section{Conclusions}

Our laboratory experimental results provide a novel treatment process for metallurgical industry wastewater, which includes As and $\mathrm{Cd}$ adsorptive removal, adsorbent regeneration, and recovery of As and $\mathrm{Cd}$. The granular $\mathrm{TiO}_{2}$ used in this study has unique advantages over nanocrystalline $\mathrm{TiO}_{2}$ powder because of its greater particle size. Thus, granular $\mathrm{TiO}_{2}$ can be readily installed with column-based treatment chains and the $\mathrm{TiO}_{2}$ regeneration is operationally feasible. Using this triple fixed-bed continuous process, the arsenic and coexisting heavy metals in the acidic wastewater can be removed in an on-line system. In addition, our treatment technology could achieve adsorbent regeneration and has the advantage of producing "zero" amount of sludge. This heavy metal treatment system should be applicable to smelting industries worldwide.

\section{Acknowledgments}

We acknowledge the financial support of the National Basic Research Program of China (2015CB932003), the Strategic Priority Research Program of the Chinese Academy of Sciences (XDB14020201), the National Natural Science Foundation of China (41373123, 21337004), and RCEES (YSW2013A01).

\section{Appendix A. Supplementary data}

Supplementary data related to this article can be found at http://dx.doi.org/10.1016/j.watres.2014.10.042.

\section{R E F E R E N C E S}

Adra, A., Morin, G., Ona-Nguema, G., Menguy, N., Maillot, F., Casiot, C., Bruneel, O., Lebrun, S., Juillot, F., Brest, J., 2013. Arsenic scavenging by aluminum-substituted ferrihydrites in a circumneutral $\mathrm{pH}$ river impacted by acid mine drainage. Environ. Sci. Technol. 47 (22), 12784-12792.

Allende, K.L., Fletcher, T.D., Sun, G., 2012. The effect of substrate media on the removal of arsenic, boron and iron from an acidic wastewater in planted column reactors. Chem. Eng. J. 179, 119-130.

Badruzzaman, M., Westerhoff, P., Knappe, D.R.U., 2004. Intraparticle diffusion and adsorption of arsenate onto granular ferric hydroxide (GFH). Water Res. 38 (18), 4002-4012.

Bang, S., Patel, M., Lippincott, L., Meng, X., 2005. Removal of arsenic from groundwater by granular titanium dioxide adsorbent. Chemosphere 60 (3), 389-397.

Barrett, J.R., 2012. A potential window onto early pancreatic cancer development: evidence of cancer stem cell growth after exposure to cadmium chloride in vitro. Environ. Health Perspect. 120 (9), a363.

Bian, Z., Miao, X., Lei, S., Chen, S., Wang, W., Struthers, S., 2012. The challenges of reusing mining and mineral-processing wastes. Science 337 (6095), 702-703.

Collins, C.R., Ragnarsdottir, K.V., Sherman, D.M., 1999. Effect of inorganic and organic ligands on the mechanism of cadmium sorption to goethite. Geochim. Cosmochim. Acta 63 (19), 2989-3002.

Crittenden, J.C., Weber, W.J., 1978a. Predictive model for design of fixed-bed adsorbers: single-component model verification. J. Environ. Eng. Div. 104 (3), 433-443.

Crittenden, J.C., Weber, W.J., 1978b. Predictive model for design of fixed-bed adsorbers: parameter estimation and model development. J. Environ. Eng. Div. 104 (2), 185-197.

Cui, J., Shi, J., Jiang, G., Jing, C., 2013. Arsenic levels and speciation from ingestion exposures to biomarkers in Shanxi, China: implications for human health. Environ. Sci. Technol. 47 (10), $5419-5424$.

Deschamps, E., Ciminelli, V.S.T., Höll, W.H., 2005. Removal of $\mathrm{As}(\mathrm{III})$ and $\mathrm{As}(\mathrm{V})$ from water using a natural $\mathrm{Fe}$ and $\mathrm{Mn}$ enriched sample. Water Res. 39 (20), 5212-5220.

Dey, M., Williams, K., Coulton, R., 2009. Treatment of arsenic rich waters by the HDS process. J. Geochem. Explor 100 (2), 160-162.

Dong, H., Guan, X., Wang, D., Li, C., Yang, X., Dou, X., 2011. A novel application of $\mathrm{H}_{2} \mathrm{O}_{2}-\mathrm{Fe}$ (II) process for arsenate removal from synthetic acid mine drainage (AMD) water. Chemosphere 85 (7), 1115-1121.

Dou, X., Mohan, D., Pittman Jr., C.U., 2013. Arsenate adsorption on three types of granular schwertmannite. Water Res. 47 (9), $2938-2948$.

Gao, Y., Wahi, R., Kan, A.T., Falkner, J.C., Colvin, V.L., Tomson, A.B., 2004. Adsorption of cadmium on anatase nanoparticles-effect of crystal size and pH. Langmuir 20 (22), 9585-9593.

Gibbons, M.K., Gagnon, G.A., 2010. Adsorption of arsenic from a Nova Scotia groundwater onto water treatment residual solids. Water Res. 44 (19), 5740-5749.

Guan, X., Du, J., Meng, X., Sun, Y., Sun, B., Hu, Q., 2012. Application of titanium dioxide in arsenic removal from water: a review. J. Hazard. Mater. 215, 1-16.

Janusz, W., Matysek, M., 2006. Coadsorption of Cd(II) and oxalate ions at the $\mathrm{TiO}_{2}$ /electrolyte solution interface. J. Colloid Interface Sci. 296 (1), 22-29.

Jiang, Y., Hua, M., Wu, B., Ma, H., Pan, B., Zhang, Q., 2014. Enhanced removal of arsenic from a highly laden industrial effluent using a combined coprecipitation/nano-adsorption process. Environ. Sci. Pollut. Res. 21 (10), 6729-6735.

Jing, C., Cui, J., 2011. A Method of Granular $\mathrm{TiO}_{2}$ Adsorbent Synthesis for Drinking Water Purification, 201110022984.X.

Johnson, D.B., Hallberg, K.B., 2005. Acid mine drainage remediation options: a review. Sci. Total Environ. 338 (1), 3-14. Kanematsu, M., Young, T.M., Fukushi, K., Green, P.G., Darby, J.L., 2012. Individual and combined effects of water quality and 
empty bed contact time on As(V) removal by a fixed-bed iron oxide adsorber: implication for silicate precoating. Water Res. 46 (16), 5061-5070.

Liu, J., Cheng, H., Zhao, F., Dong, F., Frost, R.L., 2013. Effect of reactive bed mineralogy on arsenic retention and permeability of synthetic arsenic-containing acid mine drainage. J. Colloid Interface Sci. 394, 530-538.

Lubin, J.H., Moore, L.E., Fraumeni Jr., J.F., Cantor, K.P., 2008. Respiratory cancer and inhaled inorganic arsenic in copper smelters workers: a linear relationship with cumulative exposure that increases with concentration. Environ. Health Perspect. 116 (12), 1661-1665.

Luo, T., Cui, J., Hu, S., Huang, Y., Jing, C., 2010. Arsenic removal and recovery from copper smelting wastewater using $\mathrm{TiO}_{2}$. Environ. Sci. Technol. 44 (23), 9094-9098.

Luo, T., Tian, H., Guo, Z., Zhuang, G., Jing, C., 2013. Fate of arsenate adsorbed on Nano- $\mathrm{TiO}_{2}$ in the presence of sulfate reducing bacteria. Environ. Sci. Technol. 47 (19), 10939-10946.

McDonald, D.M., Webb, J.A., Taylor, J., 2006. Chemical stability of acid rock drainage treatment sludge and implications for sludge management. Environ. Sci. Technol. 40 (6), 1984-1990.

Mohan, D., Pittman Jr., C.U., 2007. Arsenic removal from water/ wastewater using adsorbents-a critical review. J. Hazard. Mater. 142 (1), 1-53.

Mueller, K., Ciminelli, V.S.T., Dantas, M.S.S., Willscher, S., 2010. A comparative study of $\mathrm{As}(\mathrm{III})$ and $\mathrm{As}(\mathrm{V})$ in aqueous solutions and adsorbed on iron oxy-hydroxides by Raman spectroscopy. Water Res. 44 (19), 5660-5672.

Nishimura, T., Robins, R., 1998. A re-evaluation of the solubility and stability regions of calcium arsenites and calcium arsenates in aqueous solution at $25^{\circ} \mathrm{C}$. Min. Process. Extr. Metall. Rev. 18 (3-4), 283-308.

Pantuzzo, F.L., Ciminelli, V.S.T., 2010. Arsenic association and stability in long-term disposed arsenic residues. Water Res. 44 (19), 5631-5640

Pena, M., Meng, X., Korfiatis, G.P., Jing, C., 2006. Adsorption mechanism of arsenic on nanocrystalline titanium dioxide. Environ. Sci. Technol. 40 (4), 1257-1262.

Randall, S.R., Sherman, D.M., Ragnarsdottir, K.V., Collins, C.R., 1999. The mechanism of cadmium surface complexation on iron oxyhydroxide minerals. Geochim. Cosmochim. Acta 63 (19-20), 2971-2987.

Ravel, B., Newville, M., 2005. ATHENA, ARTEMIS, HEPHAESTUS: data analysis for X-ray absorption spectroscopy using IFEFFIT. J. Synchrotron Radiat. 12 (4), 537-541.

Wang, J.W., Bejan, D., Bunce, N.J., 2003. Removal of arsenic from synthetic acid mine drainage by electrochemical $\mathrm{pH}$ adjustment and coprecipitation with iron hydroxide. Environ. Sci. Technol. 37 (19), 4500-4506.

Westerhoff, P., Highfield, D., Badruzzaman, M., Yoon, Y., 2005. Rapid small-scale column tests for arsenate removal in iron oxide packed bed columns. J. Environ. Eng 131 (2), 262-271.

Westerhoff, P., De Haan, M., Martindale, A., Badruzzaman, M., 2006. Arsenic adsorptive media technology selection strategies. Water Qual. Res. J. Can. 41 (2), 171-184.

Xu, Z.C., Li, Q., Gao, S.A., Shang, J.K., 2010. As(III) removal by hydrous titanium dioxide prepared from one-step hydrolysis of aqueous $\mathrm{TiCl}_{4}$ solution. Water Res. 44 (19), 5713-5721.

Zeng, H., Arashiro, M., Giammar, D.E., 2008. Effects of water chemistry and flow rate on arsenate removal by adsorption to an iron oxide-based sorbent. Water Res. 42 (18), 4629-4636. 